\title{
Evaluation of The Leisure Time Attitude of Gymnastic Coaches
}

\author{
METIN ÖZLÜ1 \\ ${ }^{1}$ Kafkas Univeristy, Sarıkamış physical education and sports college, Turkey \\ Correspondence to: Assoc. Metin Özlü, Email: metinozlu42@gmail.com
}

\begin{abstract}
The working group of the research consists of 297 referees who attended the 2018 Referee-Trainer Visa Seminars of the Gymnastics Federation held in Antalya between 20-23 December 2018. Leisure Attitude Scale: LAS, developed by Ragheb and Beard in 1982 and adapted into Turkish by Akgül and Gürbüz, was used in the study. The data obtained in the study, frequency,\% distribution, mean and standard deviation (Std. Deviation) were measured, Kolmogorov-Smirnov and Shapiro-Wilk tests were used in normality analysis, Kruskal Wallis-H, Mann Whitney $\mathrm{U}$, Chi-square and Fisher Exact tests were used in comparison of the groups. In this study, which examines the attitudes of gymnastics trainers towards leisure activities; It was examined whether there was a difference in terms of gender, age and coaching level and a significant difference was found according to the variables of age and coaching level $(P<0.05)$. There is a significant difference in the cognitive dimension from the sub-dimensions of attitude towards leisure activities according to age. There is a significant difference in affective dimension from the sub-dimensions of attitude towards leisure activities according to the category of coaching level $(P<0.05)$. In addition, gymnastics trainers' attitudes towards leisure activities did not differ according to gender $(P>0.05)$. In coaching training seminars, various departments should be organized in order to make efficient use of leisure time, it is recommended to support concepts such as leisure attitude and related life quality, leisure time satisfaction, leisure physical activity restrictions, and coping with leisure time obstacles by carrying out different studies.
\end{abstract}

Keywords: Gymnastics, Coach, Leisure Attitude

\section{INTRODUCTION}

Time, which is a very valuable concept for human beings, can be considered in two groups as working time

and non-working time in terms of usage. The good use of time depends on the ability to balance the time that people allocate depending on many factors. Time is the interval through which an object moves from one point in space to another. It is the most important concept that people use to plan themselves, organize their lives or adapt to organized plans (1).

The concept of leisure time has emerged as a result of radical changes and shaping in the lives of societies. The concept of leisure, which is as old as human history, begins with the Paleolithic and Neolithic periods. Various archaeologists put forward information about this period, usually for sports and recreation purposes, made by man. During antiquity and the Middle Ages leisure pursuits were only a prerogative of aristocrats. It completely changed the Renaissance and the Reform period, the French Revolution and the Industrial Revolution after that, in the understanding of interaction and change in business life, which is considered leisure time (2).

Leisure involves the individual giving up routine activities such as work and instead engaging in enjoyable activities that are highly enjoyable. This interest can include either a productive activity or a non-productive activity. However, it does not require assuming social responsibilities linked to one's other social roles (3). Therefore, traditionally this term has been considered as a recreational process (4).

Attitude is defined as the relatively stable organization of our beliefs, feelings and behavior tendencies towards an object or a person (5). Attitude is people's assessment of other people's objects or thoughts. Some attitudes are based on feelings and values rather than facts and numbers. Attitudes can also develop through imitation in the absence of deliberate sanctions in this way.

Some attitudes are an indirect function of the genetic structure and are related to traits such as temperament or personality that are directly related to our genes $(6,7)$. Attitude, with its cognitive, affective and behavioral dimensions, is a psychological construct that is seen as an important and critical interpreter of behavior. People's attitudes and their subjective reasons to act in a certain way are the causal factors among the variables in the life of society.

On the other hand, leisure attitude is defined as the feelings, thoughts and behaviors of individuals towards leisure and leisure activities, positive or negative reactions or tendencies that consist of knowledge, skills, experiences, memories and feelings acquired in the activities they participate in $(8 ; 9)$.
For this reason, it can be said that trainers' having a positive or negative attitude towards the coaching profession can also affect their behaviors while performing their profession. In this study, it is aimed how gymnastics trainers spend their free time and how their attitudes are.

This study focuses on testing the problem of leisure time and our curiosity about how this time is spent on coaches. The fact that coaches have distinctive and specific characteristics and their potential to realize their impact on the society of the future through today's youth leads us to focus this study on the problem of how coaches make use of their leisure time. With this study, it is aimed to reveal a general profile of the trainers' leisure perceptions.

\section{MATERIAL AND METHODS}

Participants: The voluntary participants of the research consist of 297 referees who attended the 2018 Referee-Trainer Visa Seminars of the Gymnastics Federation held in Antalya between 20-23 December 2018.

Procedures: The data collection tool used in the study consists of 2 parts. In the first part of the data collection tool, statements to determine the demographic information of the participants in the research group are included. The second part is; In order to measure the attitudes of 297 trainers who attended the Referee and Trainer seminar organized by the Gymnastics Federation in Antalya in 2018, the attitudes towards their leisure time were measured with the "Leisure Attitude Scale" (LAS), which was developed by Ragheb and Beard in 1982(10) and adapted into Turkish by Akgül and Gürbüz(11).

Instruments: Leisure Attitude Scale (LAS): Developed by Ragheb and Beard (1) cognitive (eg: leisure activities are beneficial for individuals and societies) (2) affective (eg: I like to engage in leisure activities) and (3) behavioral (eg: frequent leisure activities) It consists of 3 sub-dimensions with equal distribution (12 items each) and 36 items in total. The scale is a 5-point Likert type scale (Strongly Disagree- Disagree- Undecided- Agree- Strongly Agree). A minimum of 36 points and a maximum of 180 points can be obtained from the scale.

Data analysis: The data obtained in the study were presented as histogram, \% distribution, mean and standard deviation (Std. Deviation). Kolmogorov-Smirnov and Shapiro-Wilk tests were used for normality analysis. Kruskal Wallis-H, Mann Whitney $\mathrm{U}$, ChiSquare and Fisher Exact tests were used in comparison of the groups. SPSS 22.0 package program was used for data analysis. Statistical significance level was accepted as 0.05 . In the Personal Information Form, it consists of 9 items about the trainers to determine the gender, age, educational status, coaching level, 
place of residence, income level, leisure time competence, difficulty in taking advantage of leisure time and belief and value effects.

\section{RESULTS}

The distribution of the participants according to their demographic characteristics is given in Table 1.

Table 1. Frequency and percentage distribution of the participants according to their descriptive characteristics

\begin{tabular}{|c|c|c|c|}
\hline Variables & Grups & $\mathbf{N}$ & $\%$ \\
\hline \multirow[t]{2}{*}{ Gender } & Male & 163 & 54,9 \\
\hline & Female & 134 & 45,1 \\
\hline \multirow[t]{2}{*}{ Age (year) } & 30 age and below & 135 & 45,5 \\
\hline & 31 age and above & 162 & 54,5 \\
\hline \multirow[t]{3}{*}{ Education Level } & Secondary school & 25 & 8,4 \\
\hline & High school & 221 & 74,4 \\
\hline & Postgraduate & 51 & 17,2 \\
\hline \multirow[t]{5}{*}{ Coaching Level } & 1st level & 75 & 25,3 \\
\hline & 2nd level & 146 & 49,2 \\
\hline & 3rd level & 65 & 21,9 \\
\hline & 4th level & 6 & 2,0 \\
\hline & 5th level & 5 & 1,7 \\
\hline \multirow[t]{3}{*}{ Residence Area } & Rural Area & 17 & 5,7 \\
\hline & Kentsel Alan & 158 & 53,2 \\
\hline & Metropolis & 122 & $\frac{5 j, 2}{41,1}$ \\
\hline \multirow[t]{5}{*}{ Income Level } & Too bad & 6 & 2,0 \\
\hline & Bad & 42 & 14,1 \\
\hline & Ordinary & 158 & 53,2 \\
\hline & Good & 83 & 27,9 \\
\hline & Very good & 8 & 2,7 \\
\hline \multirow[t]{5}{*}{ Leisure Proficiency } & Absolutely Poor & 49 & 16,5 \\
\hline & Insufficient & 99 & 33,3 \\
\hline & Normal & 95 & 32,0 \\
\hline & Sufficient & 48 & 16,2 \\
\hline & Absolutely Sufficient & 6 & 2,0 \\
\hline \multirow[t]{3}{*}{ Leisure Time Difficulty } & Always & 162 & 54,5 \\
\hline & Sometimes & 66 & 22,2 \\
\hline & Never & 69 & 23,2 \\
\hline \multirow[t]{3}{*}{ Faith or Value Impact } & Yes & 58 & 19,5 \\
\hline & Not & 160 & 53,9 \\
\hline & Partly & 79 & 26,6 \\
\hline
\end{tabular}

${ }^{*} \mathrm{P}<0.05$

When we look at the age and gender information of the referees, it

is seen that most of the referees, regardless of women and men, are 31 years old and over.

Table 2. Comparison of Leisure Attitude Scale (LAS) scores according to gender variable

\begin{tabular}{llccccccc} 
Subscales & Gender & $\mathbf{N}$ & $\overline{\mathbf{x}}$ & Sd. & $\begin{array}{c}\text { Average } \\
\text { Rank }\end{array}$ & $\begin{array}{c}\text { Sum of } \\
\text { Average } \\
\text { Ranks }\end{array}$ & $\mathbf{U}$ & $\mathbf{P}$ \\
\hline Cognitive & Male & 163 & 49,73 & 7,09 & 147,51 & 24043,50 & 10677,500 &, 740 \\
\cline { 2 - 9 } & Female & 134 & 49,94 & 7,09 & 150,82 & 20209,50 & & \\
\hline Affective & Male & 163 & 48,47 & 8,61 & 146,91 & 23946,00 & 10580,000 &, 643 \\
\cline { 2 - 9 } & Female & 134 & 48,36 & 7,12 & 151,54 & 20307,00 & & \\
\hline Behavioral & Male & 163 & 44,24 & 8,10 & 151,10 & 24628,50 & 10579,500 &, 642 \\
\cline { 2 - 9 } & Female & 134 & 43,36 & 9,06 & 146,45 & 19624,50 & & \\
\hline
\end{tabular}

${ }^{*} \mathrm{P}<0.05$

When the table was examined, it was observed that the leisure time attitude scores of gymnastics trainers did not differ significantly in all sub-dimensions of the scale in the analysis of the Mann Whitney $U$ test, which was made according to the variable of gender. This finding shows that gymnastics trainers, being male or female, do not have different effects on leisure attitude.

Table 3. Comparison of LAS scores by age variable

\begin{tabular}{llccccccc}
\hline Subscales & Age Groups & $\mathbf{N}$ & $\overline{\mathbf{x}}$ & SD & $\begin{array}{c}\text { Average } \\
\text { Rank }\end{array}$ & $\begin{array}{c}\text { Sum of } \\
\text { Average } \\
\text { Ranks }\end{array}$ & $\mathbf{U}$ & P \\
\hline Cognitive & 30 age and below & 135 & 48,99 & 7,05 & 137,95 & 18623,50 & 9443,500 &, $043 *$ \\
\cline { 2 - 9 } & 31 age and above & 162 & 50,52 & 7,05 & 158,21 & 25629,50 & & \\
\hline Affective & 30 age and below & 135 & 48,26 & 7,87 & 143,71 & 19401,00 & 10221,000 &, 332 \\
\cline { 2 - 9 } & 31 age and above & 162 & 48,56 & 8,06 & 153,41 & 24852,00 & & \\
\hline Behavioral & 30 age and below & 135 & 44,07 & 8,43 & 150,76 & 20352,00 & 10698,000 &, 747 \\
\cline { 2 - 8 } & 31 age and above & 162 & 43,65 & 8,66 & 147,54 & 23901,00 & & \\
\hline
\end{tabular}

${ }^{*} \mathrm{P}<0.05$
When Table 3 is examined, in the analysis of the Kruskal Wallis $\mathrm{H}$ test performed according to the age variable of gymnastics trainers' leisure attitudes, a significant difference is found in terms of cognitive attitude $(p<.043)$.

Table 4. Comparison of LAS scores according to education level variable

\begin{tabular}{|c|c|c|c|c|c|c|c|c|c|}
\hline Subscales & $\begin{array}{l}\text { Education } \\
\text { Level }\end{array}$ & $\mathrm{N}$ & $\overline{\mathbf{x}}$ & SD & $\begin{array}{l}\text { Average } \\
\text { Rank }\end{array}$ & $\begin{array}{c}\text { Sum of } \\
\text { Average } \\
\text { Ranks }\end{array}$ & Sd & $\mathbf{P}$ & Dif. \\
\hline \multirow[t]{3}{*}{ Cognitive } & $\begin{array}{l}\text { Secondary } \\
\text { school }\end{array}$ & 25 & 46,96 & 7,17 & 109,32 & 5,887 & 2 & ,053 & - \\
\hline & High school & 221 & 50,25 & 6,30 & 152,17 & & & & \\
\hline & Postgraduate & 51 & 49,37 & 9,60 & 154,72 & & & & \\
\hline \multirow[t]{3}{*}{ Affective } & $\begin{array}{l}\text { Secondary } \\
\text { school }\end{array}$ & 25 & 45,48 & 7,58 & 108,84 & 6,173 & 2 & ,046 & $2-3$ \\
\hline & High school & 221 & 48,76 & 6,86 & 153,76 & & & & \\
\hline & Postgraduate & 51 & 48,37 & 11,66 & 148,05 & & & & \\
\hline \multirow[t]{3}{*}{ Behavioral } & $\begin{array}{l}\text { Secondary } \\
\text { school }\end{array}$ & 25 & 39,96 & 8,54 & 107,16 & 10,812 & 2 & ,004 & $\begin{array}{l}2-3 \\
3-4\end{array}$ \\
\hline & High school & 221 & 44,79 & 8,35 & 158,03 & & & & \\
\hline & Postgraduate & 51 & 41,65 & 8,61 & 130,38 & & & & \\
\hline
\end{tabular}

${ }^{*} \mathrm{P}<0.05$

When the table was examined, it was observed that the leisure time attitude scores of gymnastics trainers did not differ significantly in the ANOVA test analysis performed according to the education level variable in all sub-dimensions of the scale.

\begin{tabular}{|c|c|c|c|c|c|c|c|}
\hline Subscales & Level & $\mathrm{N}$ & Average Rank & Chi-Square & SD & $\mathbf{P}$ & Dif. \\
\hline \multirow[t]{5}{*}{ Cognitive } & 1st level & 75 & 140,12 & 7,733 & 4 &, 102 & \multirow{5}{*}{ - } \\
\hline & 2nd level & 146 & 154,51 & & & & \\
\hline & 3rd level & 65 & 149,79 & & & & \\
\hline & 4th level & 6 & 188,83 & & & & \\
\hline & 5th level & 5 & 63,10 & & & & \\
\hline \multirow[t]{5}{*}{ Affective } & 1st level & 75 & 145,45 & 13,058 & 4 & $011^{*}$ & \multirow{5}{*}{$\begin{array}{l}1-4,1-5,2-5, \\
3-4,3-5,4-5\end{array}$} \\
\hline & 2nd level & 146 & 156,35 & & & & \\
\hline & 3rd level & 65 & 138,09 & & & & \\
\hline & 4th level & 6 & 217,33 & & & & \\
\hline & 5 th level & 5 & 47,60 & & & & \\
\hline \multirow[t]{4}{*}{ Behavioral } & 1st level & 75 & 155,06 & 8,815 & 4 &, 066 & \multirow{4}{*}{ - } \\
\hline & 2nd level & 146 & 148,72 & & & & \\
\hline & 3rd level & 65 & 140,34 & & & & \\
\hline & 4th level & 6 & 227,17 & & & & \\
\hline
\end{tabular}

${ }^{*} \mathrm{P}<0.05$

When the table was examined, in the Kruskal Wallis $\mathrm{H}$ test analysis conducted according to the variable of the training level of gymnastics trainers, no significant difference was found between the sub-dimensions of the scale, cognitive attitude and behavioral attitude score, while a significant difference was observed between affective attitude scores. When we look at which coaching level group the difference is; It has been observed that there is a significant difference between the trainers holding the 1st, 2nd, 3rd and 4th level coaching certificate and the trainers with the 5th level coaching certificate in favor of the trainers with the 1st, 2nd, 3rd and 4th level coaching certificate. In addition, it has been observed that there is a significant difference between the trainers holding the 1st and 3rd level coaching certificates and the trainers with the 4th level coaching certificate in favor of the trainers with the 4th level coaching certificate.

Table 6. Comparison of LAS scores according to the residence area variable

\begin{tabular}{|c|c|c|c|c|c|c|c|c|}
\hline Subscales & $\begin{array}{l}\text { Residence } \\
\text { Area }\end{array}$ & $\mathbf{N}$ & $\overline{\mathbf{x}}$ & SD & $\begin{array}{c}\text { Average } \\
\text { Rank }\end{array}$ & $\begin{array}{l}\text { Chi- } \\
\text { Square }\end{array}$ & SD & p \\
\hline \multirow[t]{3}{*}{ Cognitive } & Rural Area & 17 & 50,24 & 5,71 & 140,41 & 869 & 2 & ,648 \\
\hline & $\begin{array}{l}\text { Kentsel } \\
\text { Alan }\end{array}$ & 158 & 49,44 & 7,31 & 145,79 & & & \\
\hline & Metropolis & 122 & 50,27 & 6,96 & 154,36 & & & \\
\hline \multirow[t]{3}{*}{ Affective } & Rural Area & 17 & 51,24 & 5,45 & 180,26 & 2,862 & 2 & 239 \\
\hline & $\begin{array}{l}\text { Kentsel } \\
\text { Alan }\end{array}$ & 158 & 48,23 & 8,12 & 144,03 & & & \\
\hline & Metropolis & 122 & 48,27 & 8,03 & 151,07 & & & \\
\hline \multirow[t]{3}{*}{ Behavioral } & Rural Area & 17 & 44,94 & 7,64 & 157,53 & ,994 & 2 & ,608 \\
\hline & $\begin{array}{l}\text { Kentsel } \\
\text { Alan }\end{array}$ & 158 & 44,13 & 8,54 & 152,55 & & & \\
\hline & Metropolis & 122 & 43,32 & 8,70 & 143,22 & & & \\
\hline
\end{tabular}

${ }^{*} \mathrm{P}<0.05$ 
When the table was examined, it was observed that the leisure attitudes of gymnastics trainers did not differ significantly in all sub-dimensions of the scale in the analysis of Kuruscalvaris test performed according to the place of residence variable.

Table 7. Comparison of LAS scores according to the variable of income status

\begin{tabular}{|c|c|c|c|c|c|c|c|c|}
\hline Subscales & $\begin{array}{l}\text { Income } \\
\text { Level }\end{array}$ & $\mathbf{N}$ & $\overline{\mathbf{x}}$ & SD & $\begin{array}{c}\text { Average } \\
\text { Rank }\end{array}$ & $\begin{array}{c}\text { Chi- } \\
\text { Square }\end{array}$ & SD & $\mathbf{P}$ \\
\hline \multirow[t]{5}{*}{ Cognitive } & Too bad & 6 & 46,17 & 11,53 & 129,08 & 4,185 & 4 &, 382 \\
\hline & Bad & 42 & 50,93 & 6,69 & 153,85 & & & \\
\hline & Ordinary & 158 & 49,66 & 6,26 & 145,37 & & & \\
\hline & Good & 83 & 50,33 & 8,03 & 159,28 & & & \\
\hline & Very good & 8 & 44,75 & 8,68 & 103,56 & & & \\
\hline \multirow[t]{5}{*}{ Affective } & Too bad & 6 & 46,67 & 10,98 & 141,42 & 3,043 & 4 &, 551 \\
\hline & $\mathrm{Bad}$ & 42 & 49,95 & 10,01 & 156,35 & & & \\
\hline & Ordinary & 158 & 47,95 & 7,54 & 143,47 & & & \\
\hline & Good & 83 & 48,92 & 7,52 & 159,10 & & & \\
\hline & Very good & 8 & 45,88 & 6,10 & 120,56 & & & \\
\hline \multirow[t]{5}{*}{ Behavioral } & Too bad & 6 & 45,83 & 11,05 & 170,50 & 7,496 & 4 &, 112 \\
\hline & $\mathrm{Bad}$ & 42 & 41,93 & 8,20 & 127,56 & & & \\
\hline & Ordinary & 158 & 43,41 & 8,83 & 144,75 & & & \\
\hline & Good & 83 & 45,61 & 7,98 & 167,63 & & & \\
\hline & Very good & 8 & 42,63 & 6,57 & 136,06 & & & \\
\hline
\end{tabular}

${ }^{*} \mathrm{P}<0.05$

When the table was examined, it was observed that the leisure attitudes of gymnastics trainers did not differ significantly in all sub-dimensions of the scale in the analysis of the Anova test, which was made according to the income variable.

Table 8. Comparison of LAS scores according to the proficiency level of leisure time

\begin{tabular}{|c|c|c|c|c|c|c|c|c|}
\hline Subscales & $\begin{array}{l}\text { Proficiency Level of } \\
\text { Leisure Time }\end{array}$ & $\mathbf{N}$ & $\overline{\mathbf{x}}$ & SD & $\begin{array}{l}\text { Average } \\
\text { Rank }\end{array}$ & $\begin{array}{l}\text { Chi- } \\
\text { Square }\end{array}$ & SD & $\mathbf{P}$ \\
\hline \multirow[t]{5}{*}{ Cognitive } & Absolutely Poor & 49 & 50,14 & 7,04 & 151,61 & 1,000 & 4 & .910 \\
\hline & Insufficient & 99 & 49,46 & 7,46 & 145,84 & & & \\
\hline & Normal & 95 & 50,40 & 6,64 & 154,84 & & & \\
\hline & Sufficient & 48 & 49,35 & 7,02 & 142,92 & & & \\
\hline & Absolutely Sufficient & 6 & 47,83 & 9,43 & 136,00 & & & \\
\hline \multirow[t]{5}{*}{ Affective } & Absolutely Poor & 49 & 47,69 & 6,94 & 137,73 & 1,080 & 4 &, 897 \\
\hline & Insufficient & 99 & 48,26 & 7,56 & 150,17 & & & \\
\hline & Normal & 95 & 48,95 & 9,05 & 151,72 & & & \\
\hline & Sufficient & 48 & 48,56 & 7,78 & 153,13 & & & \\
\hline & Absolutely Sufficient & 6 & 47,50 & 6,95 & 145,67 & & & \\
\hline \multirow[t]{5}{*}{ Behavioral } & Absolutely Poor & 49 & 42,22 & 7,06 & 127,57 & 5,977 & 4 & ,201 \\
\hline & Insufficient & 99 & 44,47 & 8,05 & 156,57 & & & \\
\hline & Normal & 95 & 43,49 & 8,86 & 144,65 & & & \\
\hline & Sufficient & 48 & 44,42 & 10,11 & 158,99 & & & \\
\hline & Absolutely Sufficient & 6 & 47,50 & 9,01 & 188,08 & & & \\
\hline
\end{tabular}

${ }^{*} \mathrm{P}<0.05$

When the table was examined, it was observed that the leisure attitudes of gymnastics trainers did not differ significantly in all sub-dimensions of the scale in the Anova test analysis, which was made according to the efficiency variable of leisure time.

Table 9. Comparison of LAS scores according to difficulty in evaluating leisure time

\begin{tabular}{|c|c|c|c|c|c|c|c|c|c|}
\hline Subscales & $\begin{array}{l}\text { Leisure Time } \\
\text { Difficulties }\end{array}$ & $\mathrm{N}$ & $\bar{x}$ & SD & $\begin{array}{c}\text { Average } \\
\text { Rank }\end{array}$ & $\begin{array}{c}\text { Chi- } \\
\text { Square }\end{array}$ & SD & $\mathbf{P}$ & Farl \\
\hline \multirow[t]{3}{*}{ Cognitive } & Always & 66 & 49,80 & 7,93 & 151,81 & 4,768 & 2 & ,092 & - \\
\hline & Sometimes & 162 & 49,29 & 6,93 & 140,24 & & & & \\
\hline & Never & 69 & 51,10 & 6,48 & 166,88 & & & & \\
\hline \multirow[t]{3}{*}{ Affective } & Always & 66 & 47,56 & 7,12 & 140,98 & 7,033 & 2 &, $030^{*}$ & $1-3$ \\
\hline & Sometimes & 162 & 47,95 & 8,59 & 142,06 & & & & $2-3$ \\
\hline & Never & 69 & 50,35 & 6,92 & 172,97 & & & & \\
\hline \multirow[t]{3}{*}{ Behavioral } & Always & 66 & 42,80 & 8,26 & 139,85 & 3,368 & 2 & , 186 & - \\
\hline & Sometimes & 162 & 43,59 & 8,51 & 145,91 & & & & \\
\hline & Never & 69 & 45,43 & 8,78 & 165,01 & & & & \\
\hline
\end{tabular}

When the table is examined; In the Kruskal Wallis $\mathrm{H}$ test analysis made according to the variable of leisure time evaluation of the leisure attitudes of gymnastics trainers, while there is a significant difference in terms of affective attitude $(p<.030)$, which are the sub-dimensions of the scale, there is no significant difference between cognitive attitude, behavioral attitude and total attitude score.
Table 10. Comparison of LAS scores according to whether beliefs or values guide leisure activities

\begin{tabular}{llccccccc} 
Subscales & $\begin{array}{l}\text { Faith or Value } \\
\text { Impact }\end{array}$ & $\mathbf{N}$ & $\overline{\mathbf{x}}$ & SD & $\begin{array}{c}\text { Average } \\
\text { Rank }\end{array}$ & $\begin{array}{c}\text { Sum of } \\
\text { Average } \\
\text { Ranks }\end{array}$ & U & P \\
\hline Cognitive & Yes & 58 & 49,4828 & 6,21329 & 101,64 & 5895,00 & 4184,000 &, 267 \\
\cline { 2 - 9 } & Not & 160 & 50,4688 & 7,07100 & 112,35 & 17976,00 & & \\
\hline Affective & Yes & 58 & 48,3621 & 10,15269 & 101,60 & 5893,00 & 4182,000 &, 265 \\
\cline { 2 - 9 } & Not & 160 & 48,8250 & 7,72365 & 112,36 & 17978,00 & & \\
\hline Behavioral & Yes & 58 & 45,6897 & 6,77251 & 120,80 & 7006,50 & 3984,500 &, 110 \\
\cline { 2 - 9 } & Not & 160 & 43,2313 & 8,82836 & 105,40 & 16864,50 & & \\
\hline
\end{tabular}

${ }^{*} \mathrm{P}<0.05$

When the table is examined, in the analysis of the Kruskal Wallis $\mathrm{H}$ test, which was performed according to the variables of difficulty in evaluating the beliefs or values of the leisure attitudes of gymnastics trainers, no significant difference was observed between affective attitude, cognitive attitude, behavioral attitude and total attitude score, which are the sub-dimensions of the scale

\section{DISCUSSION AND CONCLUSION}

As a result of the study, no significant difference was found between the leisure attitudes of gymnastics trainers and their gender ( $p>0.05)$. This finding indicates that whether gymnastics trainers are male or female, they do not affect their leisure time attitudes differently. Sports culture is thought to have an effect on the occurrence of this finding. Due to the duties that society imposes on women (cleaning, cooks, wife, mother, etc.), the time limitations women experience may affect their attitudes towards leisure time. However, it has been shown that women involved in sports are more active and comfortable due to the effect of sports, do not have limited opportunities in recreational choices due to the roles assigned to women by the society, in other words, their gender does not interfere with leisure activities.

When the literature is examined $(12 ; 13 ; 14 ; 11 ; 15 ; 16)$, it has been reported that males generally exhibit more positive attitudes than females in leisure time attitudes, and emphasized that this was due to the influence of patriarchal Turkish culture (16). On the other hand, there was no difference in all three sub-dimensions according to gender, in the studies done on Sanin (17) university students, Bakay (18) secondary school students, Deng et al. (19) British and Chinese citizens residing in Canada, Pala et al (20) Futboltenisi Athletes, Gökürek (21) individuals participating in the dance activity, Aydemir et al. (22) with individuals living in the city center of Edirne, Ayyıldız Durhan et al. (23) 'individuals engaged in recreational swimming sports, Karaman et al. (24) individuals participating in recreational dance activities. When we look at literature researches, these results are consistent with our research findings. In the literature, it is seen that there are different results between gender and leisure time (25). Related studies show that social and cultural differences have different results on the leisure attitude of gender.

While there was no significant difference between the emotional and behavioral attitude sub-dimensions of gymnastics trainers and their age ( $p>0.05)$, a significant difference was found in the cognitive attitude dimension in favor of gymnastics trainers in the 30 and under group $(p<0.05)$. Age is an important factor affecting active or passive participation in leisure activities. For example, younger people tend to use their leisure time more actively, participate in physical activity and sports activities than older individuals (26). Partially supporting our research findings, Çelik (27) found that while a significant difference was determined in the cognitive and affective sub-dimensions, there was no significant difference in the behavioral sub-dimension in his study on police college students. In the research of Çelik (27), it was determined that the younger ones tend to use their spare time more effectively. Similarly, in the research of Demir and Demir (28), it was revealed that young people participate in physical activities and sports activities more than the older ones. On the other hand, in the study of Green et al. (29), as the age of the students increases, the leisure time activities in which they learn 
more activities and that they can do in the future increase. Cheng et al. (30), in their study, which comparatively analyzed the participation of university students studying in 6 different countries in recreational sports, stated that their participation in recreational sports varies according to age. It is observed in the study of Çemrek (31) that the age difference is also important. It can be said that the leisure time evaluation styles of students in Turkey do not differ greatly and therefore their leisure time attitudes do not change according to age (11). In some studies in the relevant literature, it was found that the age of the participants was not a significant predictor of participation in leisure activities $(32 ; 21 ; 20$; $22 ; 23)$. In this study, it is seen that the leisure time attitudes of gymnastics trainers (except for the cognitive sub-dimension) do not significantly differ according to the age variable. The difference in the cognitive dimension in favor of young trainers can be related to the fact that younger people participate more in leisure activities (33). In other dimensions, gymnastics trainers of all age groups have similar attitudes in terms of using their free time.

While there was no significant difference between the affective and behavioral attitude dimensions of gymnastics trainers' leisure attitude sub-dimensions and their educational status ( $p>$ 0.05), in the studies of Balaban et al (34) on Kırkpınar Oil Wrestling Athletes and Aydemir et al (22) on leisure activities, no difference was observed in all three sub-dimensions. Parallel to the increase in the level of education, their expectations in leisure time activities are expected to increase in the same direction. In the study conducted by İleri and Sönmez (35) on individuals who are directed to physical activities, it was concluded that the main effect of the "educational status" variable on the sub-dimensions of LAS was not significant and that no sub-dimension scores of the participants differ significantly. Especially as the educational and cultural level increases, the level of participation in leisure activities also increases (36). It can be said that the way of using trainers' leisure time does not differ and therefore does not change according to education level.

In our study, no significant difference was found in the cognitive and behavioral dimensions of the leisure time attitude scale sub-dimensions of the coaching level categories of gymnastics trainers, and a significant difference was found in the affective dimension. When the results of the Mann Whitney $U$ test were examined, the trainers with the 5 th level trainer certificate in the affective dimension had a significantly lower attitude than the other levels. On the other hand, the trainers with the 4th level coaching certificate have a significantly higher attitude than the trainers with the 1 st and 3rd level coaching certificates. The occurrence of this difference may be due to the fact that the trainers with the 5th level coaching certificate cannot eliminate the negativities that may arise against the activities performed against leisure activities or their enthusiasm for leisure activities is low compared to the trainers at other levels who are assumed to be younger. Affective elements of the attitudes consist of the emotions and evaluations of the individual about the object of attitude, in other words, the person's enthusiasm for the living or non-living, intangible or concrete things that are the subject of the attitude. The object of attitude constitutes the affective element of the attitude in judgments such as, pleasant or not, liked or disliked. The affective element gives continuity to the attitude, shapes the attitude and makes the attitude repulsive (37). It is possible to say that this emotional state is seen stronger in gymnastics trainers who have 4th level coaching certificate. In line with these results, the reason for the difference between gymnastics trainers is, In line with these results, the reason for the difference between gymnastics trainers is the trainers who have 5th and 4th level coaching certificates have different (5th level negative; 4th level positive) perspectives and evaluations towards attitude objects in any event, situation or recreational activities.

Comparison of LAS scores according to the variable of residence, no significant difference was found in the cognitive, behavioral and affective dimensions of the leisure time attitude scale. In parallel with our research, it has been determined that there is no significant factor in the study of (11) attitudes of individuals from different cultures towards leisure activities, Göker (38) regarding the life satisfaction of foreign university students and their attitudes towards receiving psychological help from students from various countries and Yazıcıoğlu (39) residency status of retired civil servants participating in recreational activities.

Comparison of LAS scores according to the income variable did not differ significantly in all sub-dimensions of the scale. Akgül (11) stated in his study that it does not differ according to the income levels of the participants living in Ankara and London, and it coincides with our study. In the study conducted by Sanin (17), it is seen that Vocational School Sports Management Program students in Turkey do not differentiate according to their income levels and coincide with our study. It is seen that they do not differ according to their income levels and coincide with our study in the studies of Çakır et al. (40) examined the leisure time barriers and life satisfaction levels of public employees and Eruzun (41) investigated the effects of female participants on leisure time satisfaction and quality of life.

As a result of the comparison of LAS scores according to the leisure time competence variable, there was no significant difference in the Cognitive and Behavioral sub-dimensions, while a significant difference was found in the Affective sub-dimension. Çelik (27), in his study with the police college participants, found that there was no significant difference in the cognitive, affective and behavioral sub-dimensions of the participants' leisure time attitudes according to the variables of "weekly leisure time competence", in the findings of Akyüz and Türkmen (42) on their attitudes towards leisure time in their study on University Students, and Tolukan et al. (42) found that there was a significant difference in the "affective" sub-dimension according to the "difficulty in evaluating" variable of the participants, and there was no difference in the other sub-dimensions.

It was determined in the study conducted by Balaban et al. (34) on Kırkpınar Oil Wrestling Athletes, it was found that all subdimension mean scores, including "cognitive", "affective" and "behavioral", differed significantly in terms of the effect of "difficulty in evaluating" and in the studies of Yalçın et al. (43) the leisure time attitude average scores are higher the participants who do sports and who do not have difficulty in leisure time.

There is no significant difference between affective attitude, cognitive attitude, behavioral attitude and total attitude score, which are the sub-dimensions of the scale conducted according to the variable of leisure attitudes beliefs or values.

In the study of Dost (44), it was observed that the effects of the variable of religious belief on the life satisfaction of university students did not differ statistically and coincided with our study. Demir and Demir (28) stated in their research on university students that religious belief was among the least influential factors on participation in leisure activities also. When the studies on beliefs and values are examined, it can be thought that the young population postpones their beliefs and values or leave them to old age.

In this study, which examines the attitudes of gymnastics trainers towards leisure activities; Comparison of gymnastics trainers with regard to their leisure attitudes has been made according to some demographic variables.In future studies, it is possible to make suggestions to federations and universities by determining the necessary differences and relationships by taking into account the types of activities they participate in, activity frequency and duration, as well as the attitudes of the coaches. As a result; We should state that the research needs to be disseminated with wider participants (different branch trainers) in a way that defines the universe in depth. However, the personal variables used in this study should be increased and the importance of sport and its involvement in sports in attitude towards leisure activities can be made more evident. Various departments should be organized in coaching training seminars in order to make efficient use of leisure time. Besides, different studies can be done by considering the concepts of leisure time 
attitude and related life quality, leisure time satisfaction, restrictions of leisure physical activity, and coping with leisure time obstacles in the theories in the literature.

\section{REFERENCES}

1. Sevil, T., Şimşek, K. Y., Katırcı, H., Çelik, O., Çeliksoy, M. A., \& Kocaekşi, S. (2012). Boş zaman ve rekreasyon yönetimi. Baskı. Eskişehir: Anadolu Üniversitesi Yayını.

2. Karaküçük, S. (2014). Rekreasyon: boş zamanları değerlendirme.

3. Marshall, G. (1999). Sociology Dictionary (trans. Osman Akınhay, Derya Kömürcü), Science and Art Publications, Ankara. pp.683-684.

4. Torkildsen, G. (2005). Leisure and recreation management. Psychology Press. p.47.

5. Morris, C. (2002). Understanding Psychology, Translated by Edt. Belgin Ayvaşık, Melike Sayıl, Ankara, Turkish Psychologists Association Publications.

6. Olson, J. M., et al. (2001). The Heritability of Attitudes: A Study of Twins. Journal of Personality and Social Psychology, 80(6): 845.

7. Aronson, E., Wilson, T. D., \& Akert, R. M. (2005). Social psychology (Vol. 5). Upper Saddle River, NJ: Prentice Hall.

8. Teaff J, Ernst, N.W. ve Ernst, M. (1975). An elderly leisure attitude schedule. 28th Annual Meeting of the Gerontological Society. Oct 26 30. Louısville, Kentucky

9. Karadeniz, F., Müftüler, M., \& Gülbeyaz, K. (2019). Investigation of University Students' Attitudes and Barriers towards Leisure Activities (Muğla Sıtkı Koçman University Example). Journal of Sports and Recreation Research, 1(2), 21-36.

10. Ragheb, M. G. \& Beard, J. G. (1982). Measuring Leisure Attitude. Journal of Leisure Research, 14(2): 155-167.

11. Akgül B. M. (2011). Evaluation of attitudes of individuals from different cultures towards leisure activities: Ankara-London example. Doctoral dissertation, Gazi University Institute of Health Sciences, Ankara, 91-92.

12. Chung, M.H. \& Philips, D.A. (2002). The Relationship Between Attitude Toward Physical Education and Leisure Time Exercise in High School Students. Phsical Educator. 59 (3):126-138.

13. Thapa B, Confer J.J., \& Mendelsohn J. (2004). Trip motivations among water-based recreationists. In paper presentation at the $2 \mathrm{nd}$ international conference on monitoring and management of visitor flows in recreational and protected areas. Rovaniemi, Finland, 208212.

14. Deng, J., Walker, G. J., \& Swinnerton, G. (2005). Leisure attitudes: A comparison between Chinese in Canada and Anglo-Canadians. Leisure/Loisir, 29(2), 239-273.

15. Lapa Yerlisu T., \& Ağyar E. (2012). Perceived freedom in leisure according to leisure participations of university Students. Hacettepe J. of Sport Sciences, 23(1), 24-33.

16. Karakullukçu, Ö. F. (2020). Examination of Pre-service Teachers' Leisure Attitudes, Spormeter, 18(1), 2020, pp.264-272.

17. Sanin, B. (2019). Investigation of Attitudes of Vocational Schools Sports Management Program Students towards Leisure Activities in Turkey, Doctoral dissertation, Marmara University, Turkey.

18. Bakay, M. (2018). Determination of secondary school students attitudes towards leisure activities. Unpublished Master's Thesis Batman University Institute of Social Sciences.

19. Mutlu, G. (2008). A Research on the Attitudes of Exercisers towards Their Leisure Time (Kayseri province example), Unpublished master's thesis, Niğde University Institute of Social Sciences.

20. Pala, A., Biner, M., Oncen, S., \& Kargün, M. (2015). Investigation of attitudes of football athletes towards leisure activities. International Journal of Sport, Exercise and Training Science, 1(2), 77-82.

21. Gökyürek, B. (2016). An Analysis of Leisure Attitudes of the Individuals Participating in Dance Activities and the Relationship Between Leisure Attitude and Life Satisfaction. International Journal Of Environmental \& Science Education, 11(10), 3285-3296.

22. Aydemir, N., Toksöz, İ., \& Adil, O. (2017). Examination of attitudes towards leisure activities: Edirne city center example. Journal of Human Sciences, 14(4), 3940-3949.

23. Ayyıldız Durhan, T., Akgül, B.M. ve Karakücük, S. (2017). An evaluation on the leisure tendencies of individuals engaged in recreational swimming. Atatürk University Journal of Physical Education and Sport Sciences, 19(4), 8-16.

24. Karaman, M., Ayyıldı,, T., Okan, I. ve Yaman, M. (2016) Investigation of the happiness, leisure attitude and life satisfaction levels of the individuals participating in the recreative dance activities and the relationship between them. International Refereed Academic Journal of Sports Health and Medical Sciences, 21, 75-93.

25. Muzindutsi, Paul-Francois, \& Diana Viljoen, (2016) SocioDemographic Factors Influencing Leisure Attitude Among Undergraduate Students at a South African Universty, 1, İnternational Journal of Social Sciences and Humanity Studies.

26. Kunz J.L, Graham K. (1996). Life Cource Changes in Alcohol Consumption in Leisure Activities of Men and Women. Journal of Drug Issues, 26, pp:805-827.

27. Çelik Z (2014). Investigation of Ankara Police College Students' Attitudes towards Leisure Activities. (Master's thesis), Ankara Gazi University / Institute of Health Sciences, Ankara.

28. Demir C, Demir N. (2006). The Relationship Between Factors Affecting Individuals' Participation in Leisure Activities and Gender: An Application for Undergraduate Students, Ege Academic Review Magazine, Ege University Faculty of Economics and Administrative Sciences, vol. 6(1), p: 36-48.

29. Green, K., Smith, A., \& Roberts, K. (2005). Young People and lifelong participation in sport and physical activity: a sociological perspective on contemporary physical education programmes in England and Wales. Leisure Studies; 24 (1): 27-43.

30. Cheng, P. \& Hashem, K.A. (2011). Comparative study on recreational sports participation among the university students [online]. [cited 2011 March 22]. Available from: URL: http://www.isdy.net/pdf/eng/2007_22.pdf.

31. Cemrek, F. (2015). Investigation of the Factors that Cause Female Fans not to Watch Football Games at Stadiums. Kafkas University. Faculty of Economics and Administrative Sciences. Journal, 6(10), 317.

32. Erenci, T. (2006). Recreation Need and Planning in a University Campus (Umuttepe Example). Kocaeli University Institute of Health Sciences, Kocaeli.

33. Luo, Lu ve Shu-Fang Kao, (2009) Leisure Participation and Leisure Satisfaction: Moderating Effects of Personality Traits,3, Vol:3, Journal of Sport and Recreation Research.

34. Balaban, İ. Sağıroğlu, İ., \& Özmaden, M. (2020). Investigation of Free Time Attitude Levels of Kırkpınar Oil Wrestling Athletes. Journal of Physical Education and Sport Sciences, 22(4), 227-241.

35. Illeri, F., \& Sönmez, A. (2019). Examination of the leisure time attitude: The adult individual example. 2nd International Recreation and Sports Management Congress, Abstract Book, 11-14 April,Bodrum / Muğla, Turkey, 77-78.

36. Bergın, David A. (1992), "Leisure Activity, Motivation, and Academic Achievement in High School Students", Journal of Leisure Research, Volume: 24, Issue: 3, pp. 225-239.

37. Güney S, 2011. Davranış Bilimleri, 6. Baskı, Nobel Akademik Yayıncılık, İstanbul, p:218- 245.

38. Göker, Y. (2013). Examining the Life Satisfaction of Foreign University Students Studying in Turkey and Their Attitudes towards Getting Psychological Help. Unpublished master's thesis, Gazi University Institute of Educational Sciences.

39. Yazıcıoğlu, M. (2010). Leisure Management and Recreational Activities: An Application on the Analysis of Recreational Activities of Civil Servants. Master's thesis, Beykent University, Istanbul.

40. Çakır, V. O., Şahin, S., Serdar, E., \& Parlakkılıç, Ş. (2016). Examination of leisure time barriers and life satisfaction levels of public employees. Journal of Tourism Theory and Research, 2(2), 192-200.

41. Eruzun, C. (2017). Investigation of the effects of women's participation in sports activities on leisure satisfaction and quality of life: Sample of members of B-fit sports centers, Master's thesis, Bartın University, Institute of Educational Sciences.

42. Tolukan, E., Şahin, M. Y., Ayyıldız, E., \& Uğurlu, A. (2017). A Study on the Impression Management Behaviors of Youth Leaders. Gaziantep University Journal of Sport Sciences, 2(2), 41-56.

43. Yalçın, İ., Ekinci, N.E., Nacar, Ç., \& Boz, M. (2018). Examination of the leisure time attitudes of physical education and sports schoo students according to some variables. I. International Recreation and Sports Management Congress, Book of Abstracts, 10-13 May, Bodrum / Muğla, Turkey, 269-270

44. Dost, M. T. (2007). Examining the life satisfaction of university students according to some variables. Pamukkale University Journal of Education, 22(22), 132-143.

45. Akyüz, H., \& Türkmen, M. (2016). Examination of university students' attitudes towards leisure activities: Bartın university example. International Journal of Sport Culture and Science, 4 (Special Issue 1), 340-357. 